
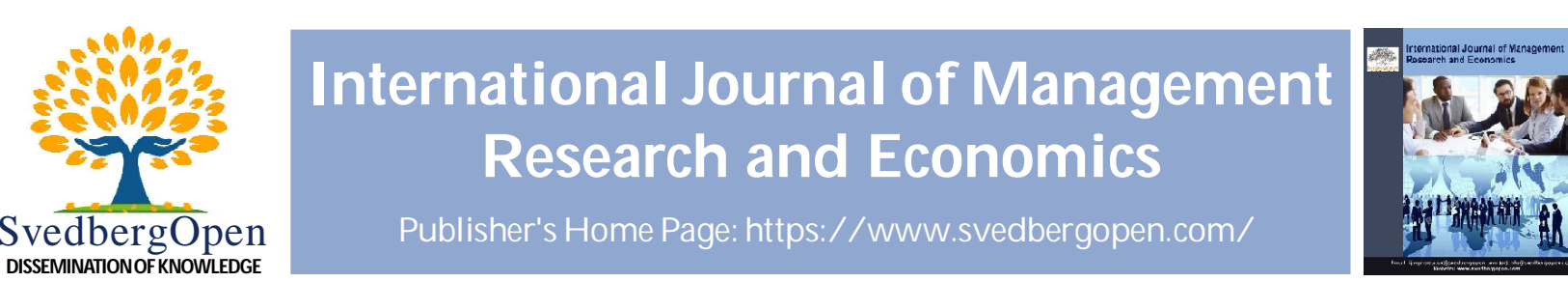

\title{
Law and economics versus the biblical worldview conflicting approaches to contract law
}

Johnny B. Davis ${ }^{1^{*}}$

${ }^{1}$ Instructor, Law and Economics, Helms School of Government, Liberty University, Lynchburg, VA 24515, United States. E-mail: jbdavis3@liberty.edu

\section{Article Info}

Volume 1, Issue 3, July 2021

Received : 17 February 2021

Accepted : 12 June 2021

Published : 05 July 2021

doi: 10.51483/IJMRE.1.3.2021.7-10

\section{Introduction}

\begin{abstract}
The American Republic was established on the foundation of natural law which held that individual rights came from mankind being made in the Image of God and that those rights were inalienable. The recognized natural law rights included the right to own property and to enter contracts and the upholding of those rights was considered the primary purpose of contract law. The Founding Fathers believed market forces were best at determining economic efficiency. Those rights established a sound foundation for the flourishing of free enterprise which turned the United States into the world's greatest economic power. In the modern era, many judges have adopted the law and economics theory of contract law. Law and economics theory rejects the idea that the primary purpose of contract law is upholding the individual rights to own property but rather to advance economic efficiency which might involve judges overturning or more often modifying the terms of a contract to maximize economic efficiency. The Biblical Natural Law of the Founding Fathers provides a better basis for contract law than the law and economic theory. The law and economics theory distorts the roles of judges and goes against the proper rooting of contract in the individual rights to own property and to enter contracts.
\end{abstract}

Keywords: Nature law rights, Contract law, Economic efficiency, Economic theory

(C) 2021 Johnny B. Davis. This is an open access article under the CC BY license (https://creativecommons.org/licenses/by/4.0/), which permits unrestricted use, distribution, and reproduction in any medium, provided you give appropriate credit to the original author(s) and the source, provide a link to the Creative Commons license, and indicate if changes were made.

The biblical worldview holds that the right to contract is an inherent right that comes from man being made in the Image of God. Therefore, contract law should as a general rule require persons to uphold their oaths. Law and Economic theory holds that the right to contract is a civil right that comes from the government in order to promote economic efficiency. The two views hold many areas of agreement, especially in that promoting economic efficiency. However, the differences in the cornerstone presupposition as to the nature of the right to contract produces two very different systems of law.

A biblical worldview recognizes that there are many promises which fall outside the jurisdiction of the government to enforce and there are certain contacts that cannot be enforced because they violate the law of God. Law and economics reject moral standards and the law of God in favor of economic efficiency. A biblical worldview calls for upholding the law objectively and judges restricting themselves to judicial rulings. Law and Economics theory allows judges to make municipal or public policy decision in order to create rules which reduce transition costs and that promote economic efficiency.

\footnotetext{
* Corresponding author: Johnny B. Davis, Instructor, Helms School of Government, Liberty University, xxxxxxxxx. E-mail: jbdavis3@liberty.edu
} 
Law and Economics legal theory holds that the primary purpose of contract law should be to maximize economic efficiency and reduce transition costs. The law and economics view does not recognize any moral standards as relevant to contract law and views the right to contract as coming from the civil government. A biblical worldview holds that the right to contract inherent right that comes from man being made in the Image of God. Therefore, contract law should as a general rule require persons to uphold their oaths. However, a biblical worldview recognizes that there are many promises which fall outside the jurisdiction of the government to enforce and there are certain contacts that cannot be enforced because they violate the law of nature and nature's God.

\section{Analysis}

The law and economics scholars reject moral or natural law as having any role in contract law. A biblical worldview holds that contract law is rooted in the law of God. Both worldviews hold that most contracts should be upheld and that economic efficiency is a good thing. However, a biblical worldview rejects the idea that economics is either the only factor or that economic efficiency is the chief factor in contract law. ${ }^{1}$ Rather the chief factor is that man is made in the Image of God and from that comes the right to contact. ${ }^{2}$ Therefore, man should, like God, keep his promises. ${ }^{3}$

\section{Common-law contract law}

Common-law contract law was rooted in a biblical worldview and recognized that moral factors were the fundamental foundation for contract law. Common-law presupposed that the foundation of contract law was that God expected all men to keep their word unless it violated His law. Not all promises were subject to judicial enforcement as most promises were the subject of the individual's accountability to God, the family, and the Church. Contract law enforcement was basically restricted to areas where both parties exchanged goods or services or spending money or undertaking service in response to a promise. ${ }^{4}$

Common-law recognized the two major purposes of contract law were to uphold oath keeping and allow contracts to facilitate the caring out of God's command to be fruitful and take dominion of the earth. Like law and economics, Common-law contract law both express and implied are recognized where all the elements are present for a contract. The elements were an agreement, sufficient consideration, and sufficient meeting of minds to do or not do a certain thing. The overarching principles of biblical and common law contract law are the same which are "sanctity of promise, the right to contract, the necessity of an agreement and consideration." 5

\section{Biblical foundation of contract-law}

God expects man to keep all his promises just as God keeps all his promises. However, the courts only have limited jurisdiction over the types of promises they can enforce. Therefore, the parties must have intended to enter into a contract with agreement and consideration for both parties. A promise to do a favor or a good deed is not a contract and courts have no authority to enforce it. Jurisdiction and accountability are found in the Church in regards to relations between believers, the family in regards to family promises, and the rest between the person and God. ${ }^{6}$

The Founding Fathers built American contact law on biblical principles and held an even more strongly biblical contract view. Most Founding Fathers agreed with James Kent's views that the right to own property, to exchange property, and to contract were all God-given rights were served the purpose of man glorifying God by taking dominion of the Earth and being fruitful. Blackstone and most of the Common Law has viewed the right to exchange land as a civil right given by the state. ${ }^{7}$ The Founding Fathers even added a clause forbidding states from impairing contract obligations. ${ }^{8}$

The Founding Fathers established a republic in which prudential or public policy decisions were restricted to legislative and executive branches which most decisions residing in the legislative branch. The judicial branch was restricted to judicial matters which involves only applying the legal standards to the case or controversy before the courts. ${ }^{9}$ Posner's Law and Economics system requires the courts to make extensive prudential and public policy decisions.

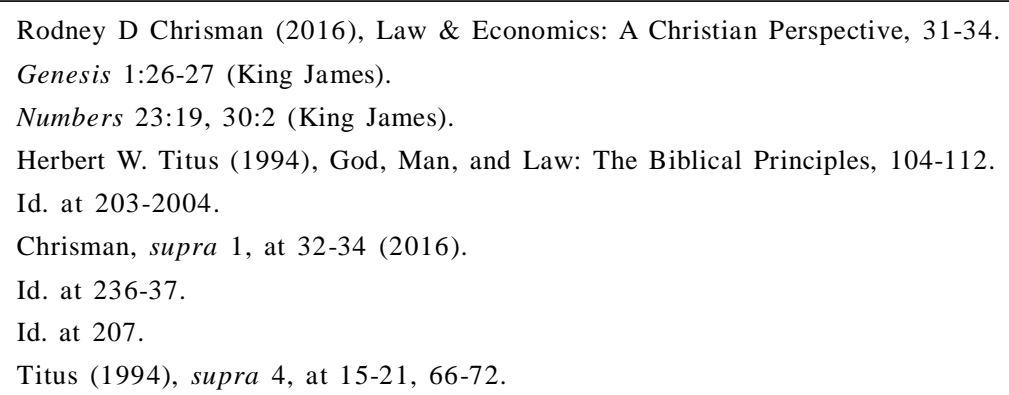


Law and economics permits courts to invent many new legal standards in the name of economic efficiency. Law and Economic theory contain no inherent limitation on how far the courts can go in making prudential and public policy decisions. Rather, Posner encourages courts to be bold in advancing their ideological agendas. ${ }^{10}$

\section{The foundations of the law and economics}

Posner's Law and Economics theory rejects any rooting of contract law in the morality of biblical principles. Posner only considers economic efficiency and the reduction of transition costs. So in some cases, law and economics allows breaches not because of fraud or a breach of contract by the other party but becomes an economically efficient breach. Posner argues that a judge can determine if a breach of a contract is efficient by weighing the costs of performance against the benefit to the other party. Thus, judges can allow contracts to be breached for numerous reasons including the impossibility of performance, unforeseen circumstances, and at any time a breach is deemed to an efficient breach. ${ }^{11}$

Posner's efficient breach doctrine requires a judge to decide the economic efficiency of a contract. A judge has no such role under biblical principles, the Constitution, or the principles of the founding fathers. ${ }^{12}$ A judge deciding economic efficiency is taking on prudential/public policy role and is second-guessing the parties to the contracts. The parties should decide the value of performance, not a judge. ${ }^{13}$ A better remedy, to higher than expected costs, is to allow a party to seek a voluntary renegotiation of the contract not for a judge to intervene when there has been no fraud or any wrongdoing.

Posner's approach is based on a false premise that expertise and economic analysis can determine economic efficiency. Economic efficiency can only be properly determined by market forces, not by a judge or anyone in government. The attempts by judges to determine economic efficiency is in and of itself central planning and government intervention which creates economic distortions. A biblical view of the law allows market forces to determine economic efficiency. The government is justified to intervene for economic reasons but to prevent or punish wrongs such as systematic fraud. ${ }^{14}$

\section{Adam Smith and law and economics}

Posner neglects the teachings of Adam Smith and has to do so since addressing Smith would demonstrate that Posner's views far from being pro-free enterprise are in fact, anti-free enterprise. Adam Smith is the great father of free enterprise classic economics. Adam Smith warns against ideological ideas like Posner. The very nature of ideologically is a fleshly pride that refuses to humble itself to the law of God. ${ }^{15}$ He understood that government's role was to punish evil and protect liberty not to ordain economic outcomes. ${ }^{16}$ Adam Smith understood the primary duty of government in regards to economics was to uphold property rights and the sanctity of contracts not to impose outcomes. ${ }^{17}$

Adam Smith developed a free enterprise system from his well thought out biblical worldview. Further, Smith argued that the law must be grounded in natural law and individual rights that come from God. ${ }^{18} \mathrm{He}$ foresaw that businessmen would seek to undermine the market. The law and economics idea is presented as a pro-business and a free-market idea. In reality, it does favor the politically powerful business interests. However, it does so by undercutting market forces and imposing outcomes. Adam Smith foresaw that businessmen would seek to use government to undermine the free market. As a result, Smith favored strong fraud laws to ensure that parties truly had a meeting of the minds. Smith understood markets needed contract enforcement to be certain and not a legal gamble with uncertain outcomes. ${ }^{19}$

\section{Biblical framework for contract law}

The biblical view of contracts is also rooted in the God's granting man stewardship over the earth and his command for man to exercise dominion over the earth. ${ }^{20}$ Thus, covenants and contracts are ordained by God in order for men to work with one another in carrying out the command of God to take dominion and to be fruitful. Therefore, all covenants and

10 Richard Posner (2011), Economic Analysis of Law, 31-35, 130-134, 170-174 .

11 Id. at 150-152, 322-323.

Alexander Hamilton, Federalist No. 78 (1788).

Chrisman (2016), supra 1, at 41-42, 45-47.

14 Titus (1994), supra 4, at 68-74, 218-224.

1 Corinthians 3:19 (King James).

16 Romans 10:3 (King James).

17 Paul G. Mahoney (2017), Adam Smith Prophet of Law and Economics, The J Legal Stud., 46, January, $216-219$.

18 Neil MacCormick (1981), Adam Smith on Law, Valparaiso Law Review, 15, 245-248, 251-254.

19 Id. at 258-263.

20 Genesis 1:15, 28-30 (King James). 
contracts must comply with the law of God are they invalid because they defeat the very purpose of covenants. Contract law is about much more than economic efficiency; it is about enabling man to fully serve God and to do his purposes. ${ }^{21}$

The biblical standard for contracts and law and economic both generally discourage government imposing terms. However, the biblical standard has a stronger objective standard against government imposition of terms in contract law. The right to contract is an inherent right of man under the biblical standard not so with Law and Economic theory in which the right to contract is granted by government to encourage economic efficiency. Thus, under the biblical standard, the government can only refuse to uphold a contract that violates the law of nature and nature's God. Under law and economics terms can be imposed by government if they promote economic efficiency such as the requirement to purchase healthcare. ${ }^{22}$

The biblical standard for contracts agrees with the Law and Economic theory on a functional level that not all promises or covenants are legal contracts that a municipal court can enforce. The parties much intend that the promises are a lawfully binding contract under the municipal authority. The reasoning behind each is very different. A biblical view holds that all promises to be kept so non-contract promises are subject to the person's accountability to God, the family, and the Church. ${ }^{23}$ The Law and Economic theory holds only economically efficient promises should be kept. Both biblical law and the law and economics theory agree that to create a binding contract there must be a meeting of the minds and a valid consideration on the part of both parties in the form of money, goods, or services in order to give jurisdiction to a municipal court. ${ }^{24}$

\section{Conclusion}

Law and economics and the biblical worldview hold some similar standards as to the particulars of contract law. The primary agreement being that contract generally should be upheld. However, the worldviews are in direct in conflict leading to significantly different standards. Law and economics reject moral standards and the law of God in favor of economic efficiency. Posner supports courts allowing economically efficient breaches of contract law. A biblical standard of contract law would not allow breaches of contract for economic efficiency.

The biblical worldview holds that the right to contract is an inherent right that comes from man being made in the Image of God. Therefore, contract law should as a general rule require persons to uphold their oaths. However, the biblical worldview recognizes that there are many promises which fall outside the jurisdiction of the government to enforce and there are certain contacts that cannot be enforced because they violate the law of God. Law and economics holds that the primary purpose of contract law should be to maximize economic efficiency and reduce transition costs. Law and economics views the right to contract as coming from the civil government.

Law and economics holds that the government in general and judges in particular broad jurisdiction and authority. Posner even believes that judges can determine economic efficiency. A biblical worldview recognizes that government, in general, has limited jurisdiction, and courts have a strict narrow judicial jurisdiction which makes prudential or public policy issues out of limits for courts. A biblical worldview recognizes that the government and especially the courts neither have the ability nor the authority to determine economic efficiency and that courts should uphold the freely entered into agreements of parties to contract as long as the terms do not violate the law of nature and nature's God.

\section{Bibliography}

Rodney D Chrisman, Law \& Economics: A Christian Perspective, (2016).

Alexander Hamilton, Federalist No. 78, (1788).

Paul G. Mahoney, Adam Smith Prophet of Law and Economics, 46 The Journal of Legal Studies 207-225 (January 2017).

Neil MacCormick, Adam Smith on Law, 15 Valparasio Law Review 242-265 (1981).

Richard Posner, Economic Analysis of Law (2011).

Herbert W. Titus, God, Man, and Law: The Biblical Principles (1994).

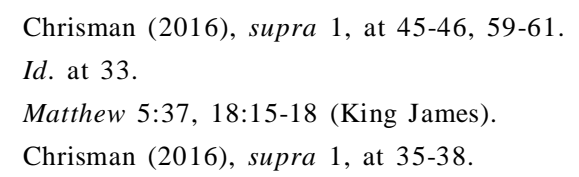

Citethis articleas: Johnny B. Davis (2021). Law and economics versus the bi blical worldview conflicting approaches to contract law. International Journal of M anagement Research and Economics. 1(3), 7-10. doi: 10.51483/ IJMRE.1.3.2021.7-10. 